

\section{DISCLAIMER}

This report was prepared as an account of work sponsored by an agency of the United States Government. Neither the United States Government nor any agency Thereof, nor any of their employees, makes any warranty, express or implied, or assumes any legal liability or responsibility for the accuracy, completeness, or usefulness of any information, apparatus, product, or process disclosed, or represents that its use would not infringe privately owned rights. Reference herein to any specific commercial product, process, or service by trade name, trademark, manufacturer, or otherwise does not necessarily constitute or imply its endorsement, recommendation, or favoring by the United States Government or any agency thereof. The views and opinions of authors expressed herein do not necessarily state or reflect those of the United States Government or any agency thereof. 


\section{DISCLAIMER}

Portions of this document may be illegible in electronic image products. Images are produced from the best available original document. 
Issued by Sandia Laboratories, operated for the United States Department of Energy by Sandia Corporation.

\section{NOTICE}

This report was prepared as an account of work spunsored by the United States Government. Neither the United States nor the Department of Energy, nor any of their employees, nor any of their contractors, subcontractors, or their employees, makes any warranty, express or implied, or assumes any legal liability or responsibility for the accuracy, completeness or usefulness of any information, apparatus, product or process disclosed, or represents that its use would not infringe privately owned rights.

SF $1004-D F(11-77)$

Printed in the United States of America

Available from

National Technical Information service

U. S. Department of Commerce

5285 Port Royal Road

Springfield, VA 22161

Price: Printed Copy $\$ 4.00$; Microfiche $\$ 3.00$ 


\section{PAGES 1 to 2 WERE INTENTIONALLY LEFT BLANK}


SAND80-1964/1

Unlimited Release

Printed November 1980
Category

UC 62

\title{
MIDTEMPERATURE SOLAR SYSTEMS TEST FACILITY PREDICTIONS \\ FOR THERMAL PERFORMANCE OF THE SOLAR \\ KINETICS T-700 SOLAR COLLECTOR \\ WITH FEK 244 REFLECTOR SURFACE
}

\author{
Thomas D. Harrison \\ Experimental Systems Operation Division \\ Sandia National Laboratories \\ Albuquerque, NM 87185
}

\begin{abstract}
Thermal performance predictions are presented for the Solar Kinetics T-700 solar collector, with FEK 244 reflector surface, for three output temperatures at five cities in the United States.
\end{abstract} Neither the United States Government nor any agency thereot, nor Bny of their employees, makes any conters disclosed, or

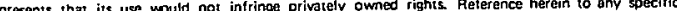
commercial Droduch, process, as service by trade name, trademark, manufacturer, or otherwise, does not necessorlily constitute or imply its endorsement, recommendation, or favoring by the United States Government or any agency thereor. The views and opinions of authors expressed herein do not necessarily state of reflect those of the United States Government or any agency thereot. 


\section{CONTENTS}

$\begin{array}{lr}\text { Introduction } & \frac{\text { Page }}{7} \\ \text { Description of the Collector } & 8 \\ \text { Results of the Test Program } & 8 \\ \text { Prediction of Thermal Performance } & 12 \\ \text { Reference } & 18\end{array}$

ILLUSTRATIONS

\section{Figure}

1 Solar Kinetics T-700 Collector

2 Peak Efficiency Plot for the Solar Kinetics T-700 Solar Collector with FEK 244 Reflector Surface

3 Heat Loss Plot for the Solar Kinetics T-700 Solar Collector with FEK 244 Reflector Surface

4 Thermal Output of the Solar Kinetics T-700 Collector with FEK 244 Reflector Surface with E-W and N-S Orientation and Fresno TMY Solar Data

5 Thermal Output of the Solar Kinetics T-70n Collector with FEK 244 Reflector Surface with $\mathrm{E}-\mathrm{W}$ and $\mathrm{N}-\mathrm{S}$ Orientation and Albuquerque TMY Solar Data

6 Thermal output of the Solar Kinetics T-700 Collector with FEK 244 Reflector Surface with E-W and N-S Orientation and Fort Worth TMY Solar Data

7 Thermal Output of the Solar Kinetics $T-700$ Collector with FEK 244 Reflector Surface with E-W and N-S Orientation and Charleston TMY Solar Data

8 Thermal output of the Solar Kinetics T-700 Collector with FEK 244 Reflector Surface with $E \omega W$ and $N-S$ Orientation and Boston TMY Solar Data 
TABLE

Table

Page

1 Predicted Annual Thermal Output

18 


\section{MIDTEMPERATURE SOLAR SYSTEMS TEST FACILITY PREDICTIONS \\ FOR THERMAL PERFORMANCE OF THE SOLAR \\ KINETICS T-700 SOLAR COLLECTOR \\ WITH FEK 244 REFLECTOR SURFACE}

Introduction

Sandia National Laboratories, Albuquerque (SNLA) is currently conducting a program to predict the performance and measure the characteristics of commercially available solar collectors that have the potential for use in industrial process heat and enhanced oil recovery applications. A detailed account of the methods used to make the predictions is given in Reference 1 . For the convenience of the reader, some of this information is repeated in this document. This document presents the thermal performance predictions for the Solar Kinetics $\mathrm{T}-700$ solar line-focusing collector. The program is limited to thermal performance only and does not include consideration of other factors, such as

1. Losses at the ends, at gaps, and from shadowing due to packing,

2. Colliector warm-up penalties,

3. Degradation of performance,

4. Cost of the collector,

5. Losses in the energy transport system and system warm-up penalties,

6. Reliability.

7. Cost of installation,

8. Cost of operation and maintenance, and

9. Wind effects.

The program is authorized by the Department of Energy, Division of Solar Thermal Energy systems, and is partially funded through the Solar Energy Research Institute. 


\section{Description of the Collector}

A photograph of the Solar Kinetics $\mathrm{T}-700$ collector is shown in Figure 1. The module has the following characteristics.

$\begin{array}{ll}\text { Reflector configuration } & \text { Parabolic trough } \\ \text { Reflective surface } & \text { FEK } 244 \\ \text { Aperture dimensions } & 2.13 \mathrm{~m} \times 6.10 \mathrm{~m}(7 \mathrm{ft} \times 20 \mathrm{ft}) \\ \text { Aperture area } & 13 \mathrm{~m}^{2}\left(140 \mathrm{ft}^{2}\right) \\ \text { Support structure } & \text { Aluminum monocoque } \\ \text { Tracking system } & \text { Shadow band (Delevan) } \\ \text { Drive mechanism } & \text { Hydraulic } \\ \text { Heat transfer fluid } & \text { Therminol-660 } \\ \text { Operating range } & 100^{\circ} \text { to } 300^{\circ} \mathrm{C}\left(212^{\circ} \text { to } 572^{\circ} \mathrm{F}\right) \\ \text { Manufacturer } & \text { Solar Kinetics } \\ & \text { P.O. Box } 10764 \\ & \text { Dallas, Texas } 75207\end{array}$

Results of the Test Program

This collector was tested at the Collector Module Test Facility (CMTF) at SNLA. From the test data, three parameters were defined.

1. Peak efficiency ( $\left.{ }_{p}\right)$-- the efficiency of the collector, when the sun's rays are at normal incidence to the aperture plane (equivalent to solar noon) expressed as a function of $\Delta t / I$. $\Delta t$ is the temperature difference between the heat transfer fluid outlet temperature and the ambient temperature in degrees centigrade. I i.s the irradiance of the sun in watts per square meter.

$$
n_{p}=66.0-23.3 \Delta t / I-1.28 .5(\Delta t / I)^{2} .
$$

Peak efficiency is plotted in Figure 2. 


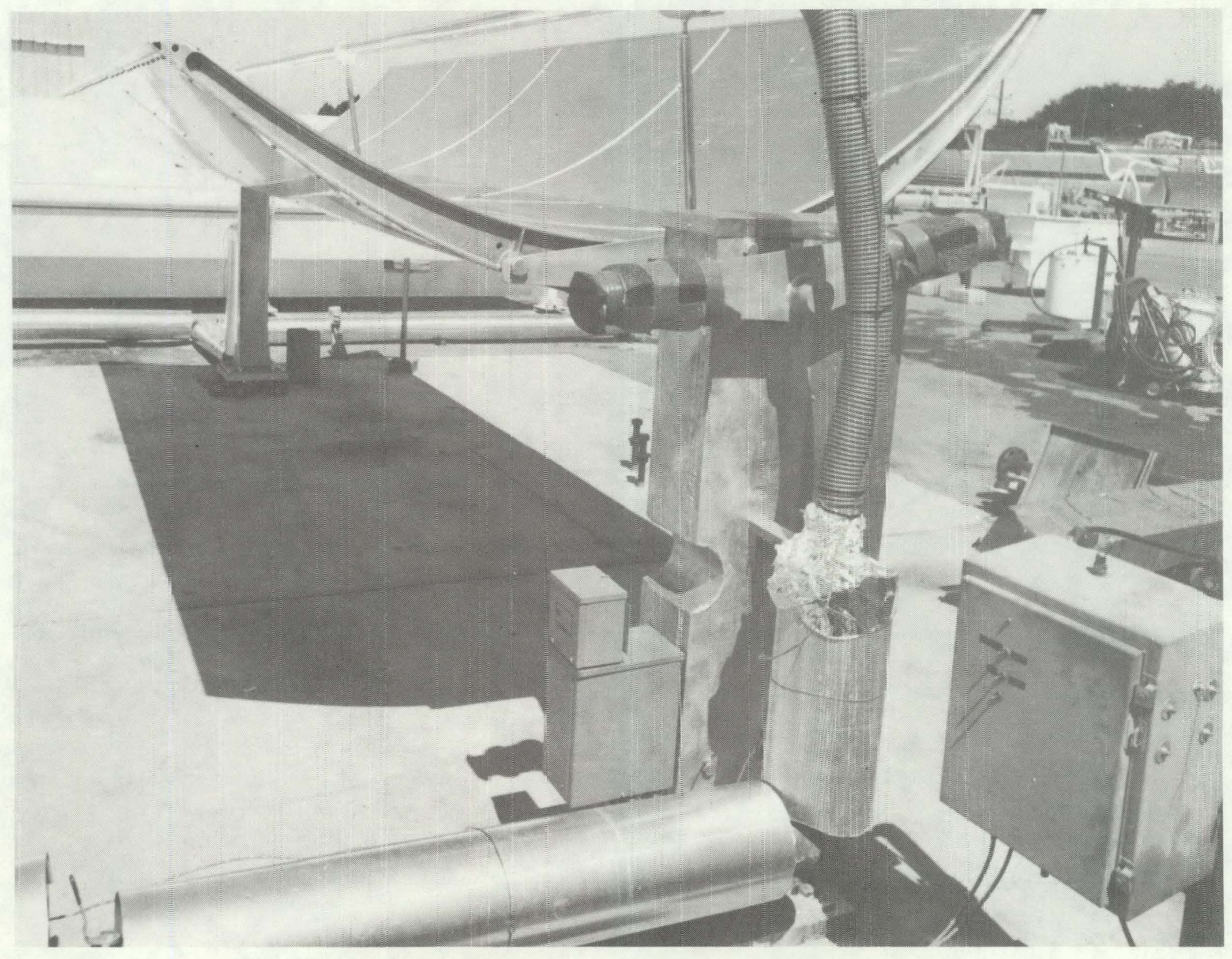




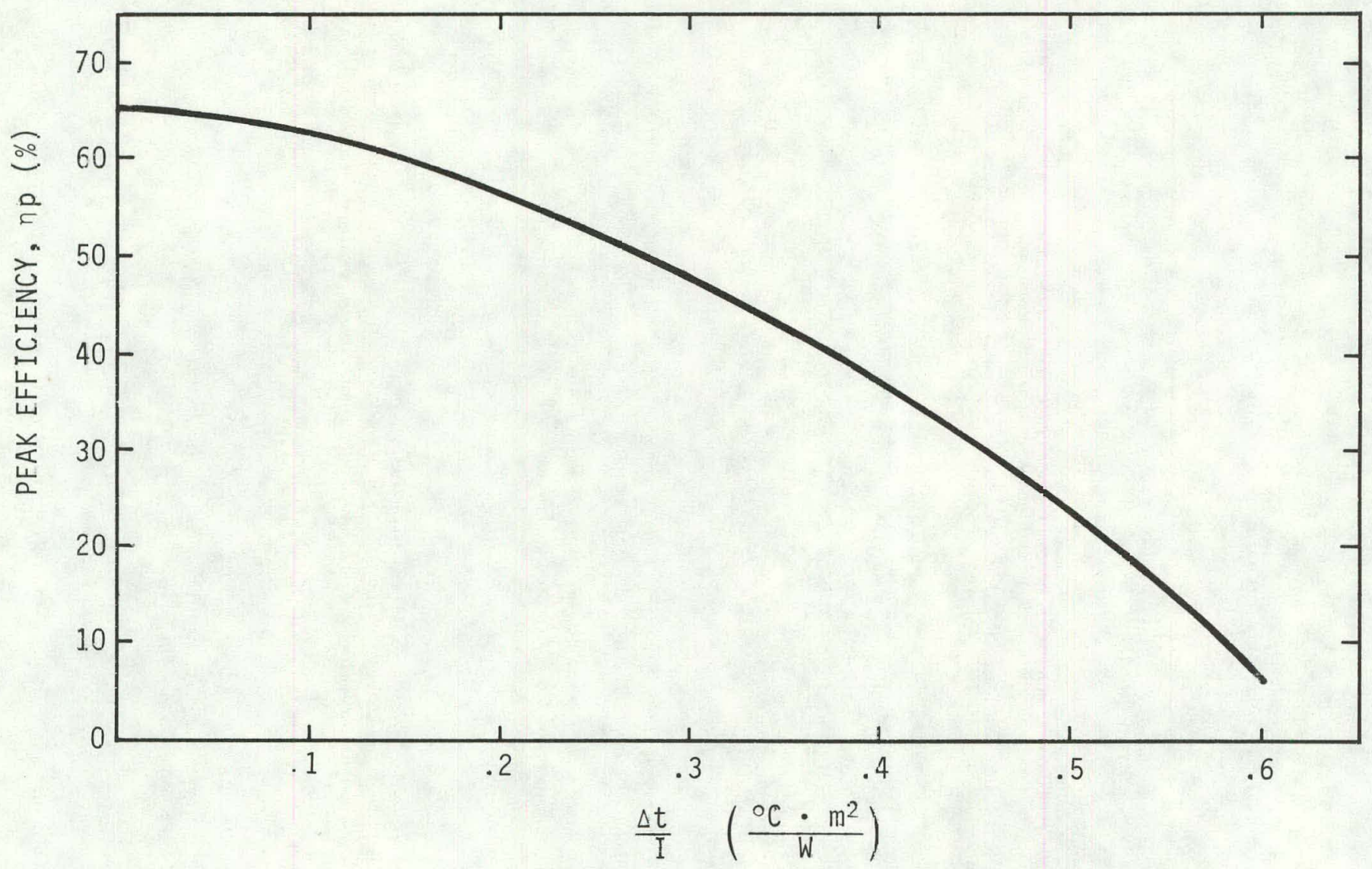

Figure 2. Peak Efficiency Plot for the Solar Kinetics T-700 Solar Collector with FEK 244 Reflector Surface 
2. Receiver thermal loss $\left(Q_{L}\right)$-- the heat lost per unit aperture area expressed as a function of $\Delta t$.

$$
\mathrm{Q}_{L}=0.00+0.233 \Delta t+1.29 \times 10^{-3}(\Delta t)^{2} \cdot\left(\mathrm{W} / \mathrm{m}^{2}\right)
$$

Heat loss is plotted in Figure 3.

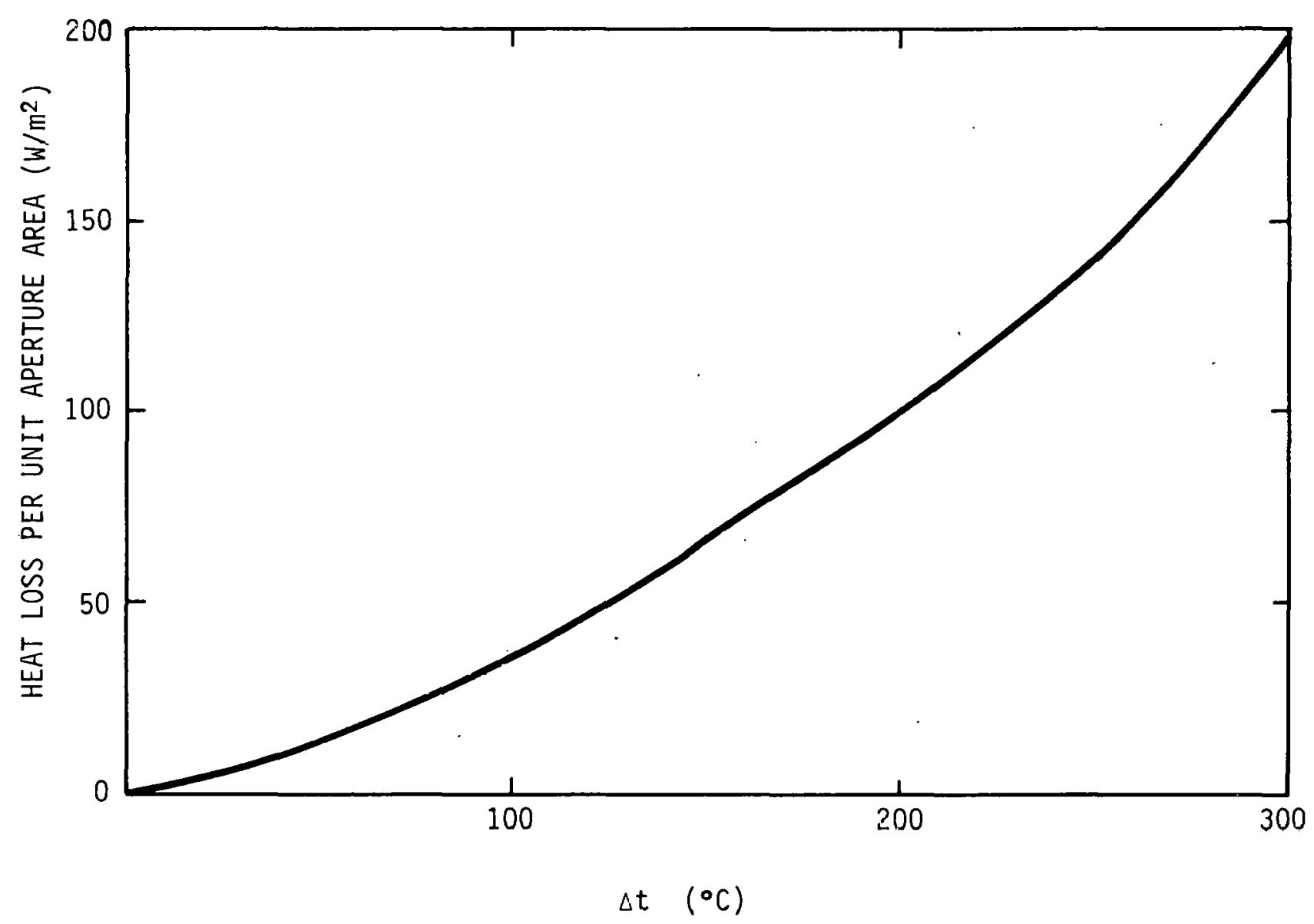

Figure 3. Heat Loss plot for the Solar Kinetics T-700 Solar rnllestor with FFK 244 Reflector Surfase

3. Optical loss coefficient $\left(K_{0}\right)--K_{O^{\prime}}$ in conjunction with the end-loss coefficient, $K_{E}$ ' and the "cosine effect," determine the incident angle modifier, $K$. Specifically, $K=K_{O} K_{E} \cos \theta$. See Reference 1. 
The values of $K_{0}$ as a function of $\theta$ are

\begin{tabular}{|c|c|c|c|}
\hline$\theta$ (degrees) & $\mathrm{K}_{\mathrm{O}}$ & $\theta$ (degrees) & $K_{0}$ \\
\hline 0 & 1.00 & 35 & 0.99 \\
\hline 5 & 1.00 & 40 & 0.95 \\
\hline 10 & 1.00 & 45 & 0.91 \\
\hline 15 & 0.99 & 50 & 0.87 \\
\hline 20 & 0.99 & 55 & 0.85 \\
\hline 25 & 0.99 & 60 & 0.82 \\
\hline 30 & 0.99 & & \\
\hline
\end{tabular}

The Solar Kinetics 'I'-\%U solar collector had been under test at the CMTF for approximately 1 year before taking the data for calculating the above parameters. It is possible that the receiver suffered some degradation in that time interval. The performance of the collector is sensitive to receiver degradation.

\section{Prediction of Thermal Performance}

A computer proqram calculates the predicted thermal performance of the collector. The performance parameters defined above are the input data describing the collector while solar and weather data are provided by TMY data tapes. With this input, the computer program calculates the thermal output of the collector for each month of the TMY in units of kilowatt hours per square meter $\left(\mathrm{kWh} / \mathrm{m}^{2}\right)$ of collector aperture area. This calculation was made for five locations: Fresno, California; Albuquerque, New Mexico; Fort Worth, Texas; Charleston, South Carolina; and Boston, Massachusetts. Three different collector output temperatures and both $\mathrm{E}-\mathrm{W}$ and $\mathrm{N}-\mathrm{S}$ orientations were considered. Figures 4 through 8 are graphical displays of the results of the computer prediction. These figures show the monthly thermal output $\left(\mathrm{kWh} / \mathrm{m}^{2} \cdot \mathrm{mo}\right)$ for each location, output temperature, and orientation. The monthly outputs have been summed to give the annual output for each parameter variation, and the results are shown in Table 1 . The computer predictions assume 1 square meter of collector aperture in the middle of a row of infinite length, with no end or gap losses and no shadowing due to packing. 

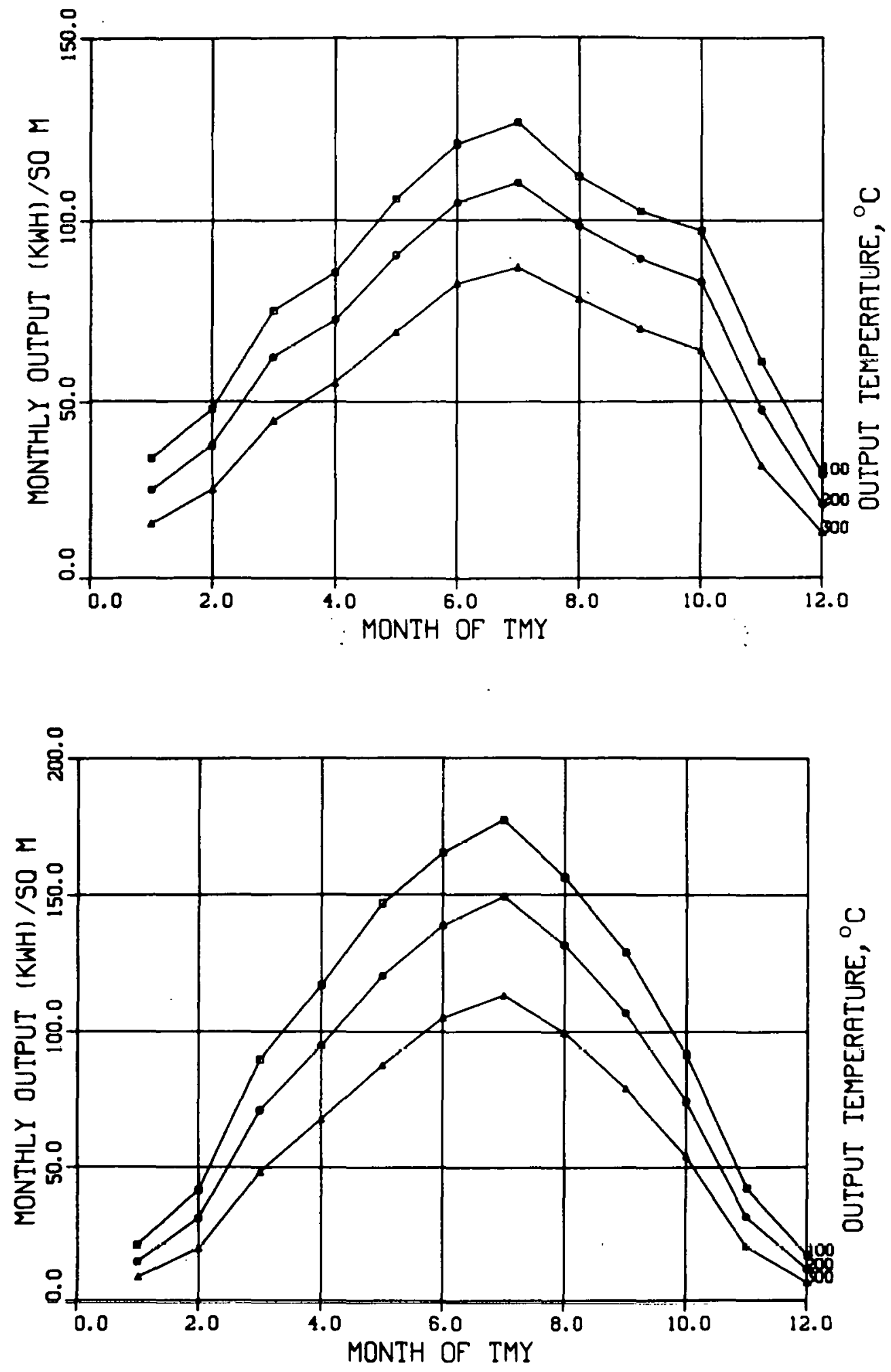

Figure 4. Thermal output of the Solar Kinetics T-700 Collector with FEK 244 Reflector Surface with E-W and N-S orientation and Fresno TMY Solar Data 

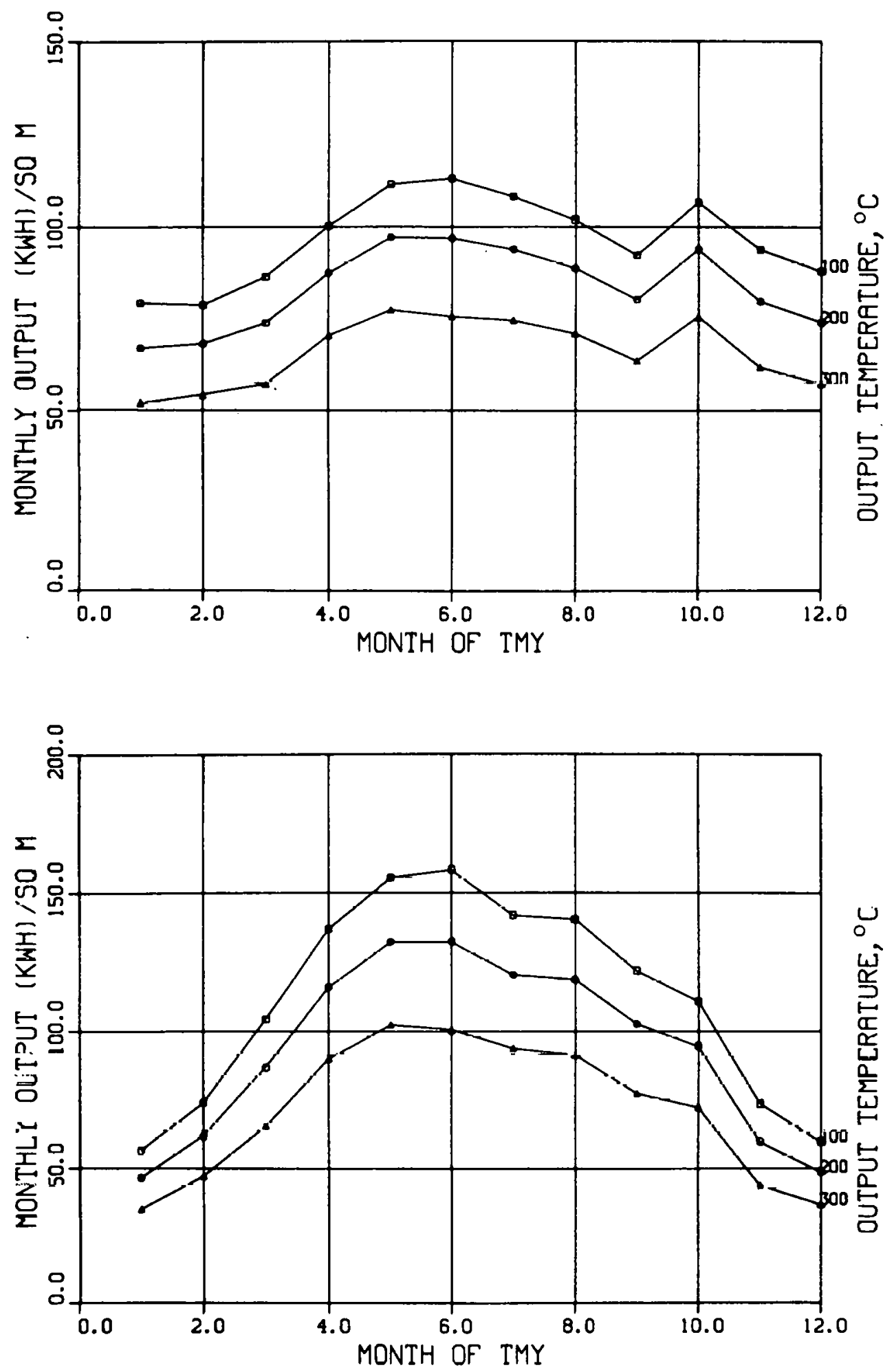

Figure 5. Thermal output of the Solar Kinetics T-700 Collector with FEK 244 Reflector Surface with E-W and N-S orientation and Albuquerque TMY Solar Data 

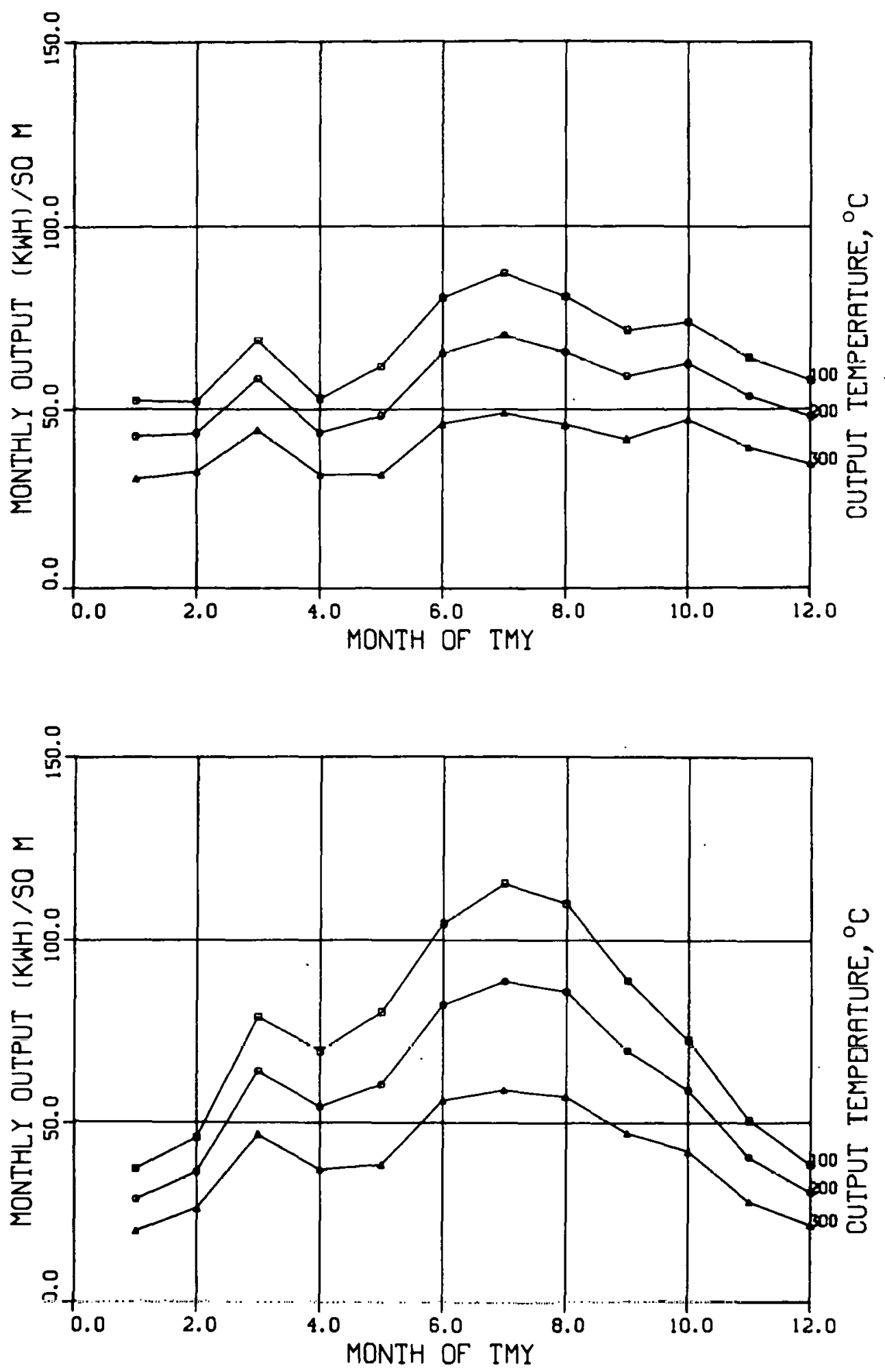

Figure 6. Thermal Output of the Solar Kinetics T-700 collertor with FFK 244 Reflector Surface with E-W and N-S Orientation and Fort Worth TMY Solar Data 

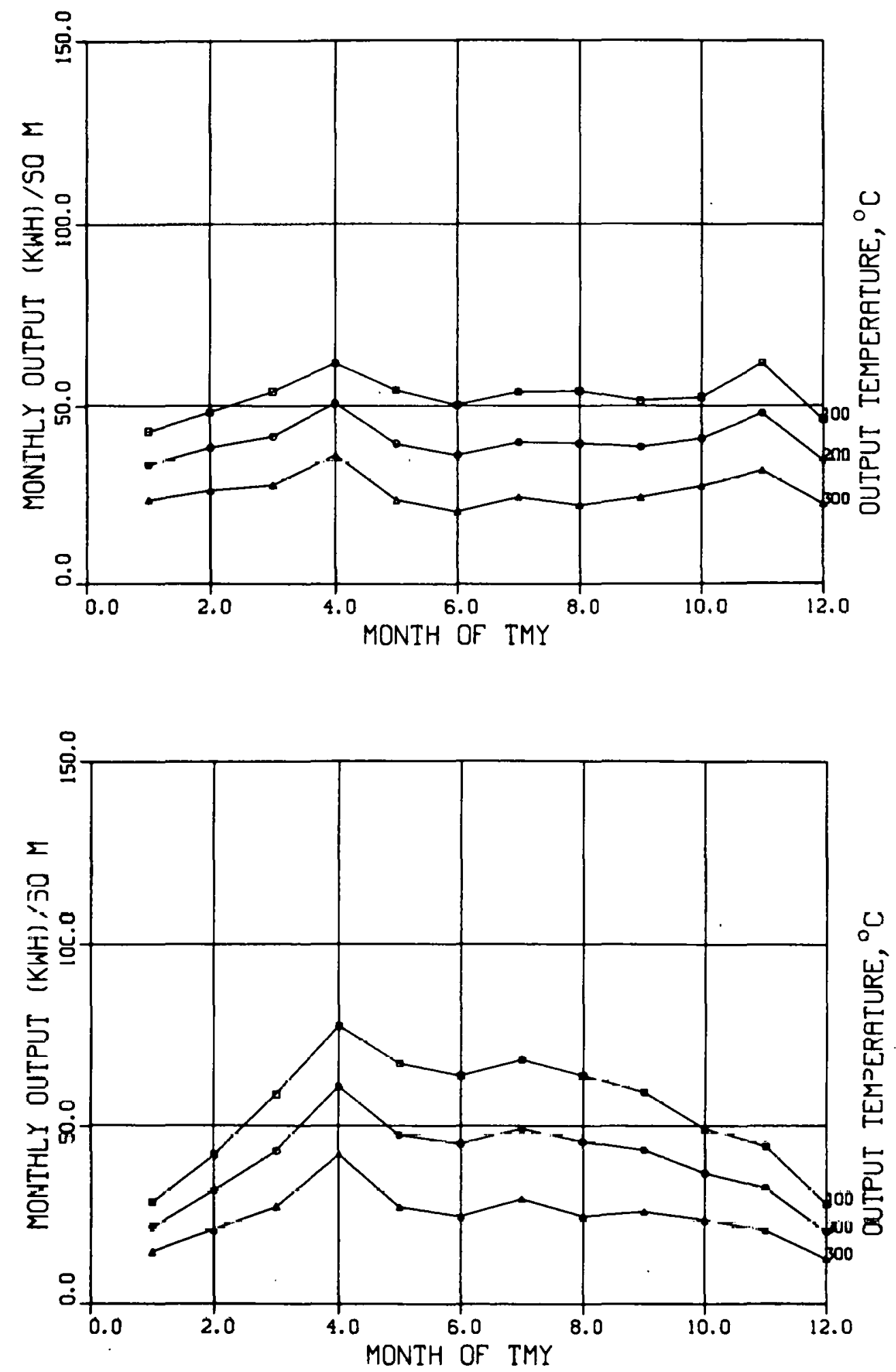

Figure 7. Thermal Output of the Solar Kinetics T-700 Collector with FEK 244 Reflector Surface with E-W and N-S orientation and Charleston TMY Solar Data 

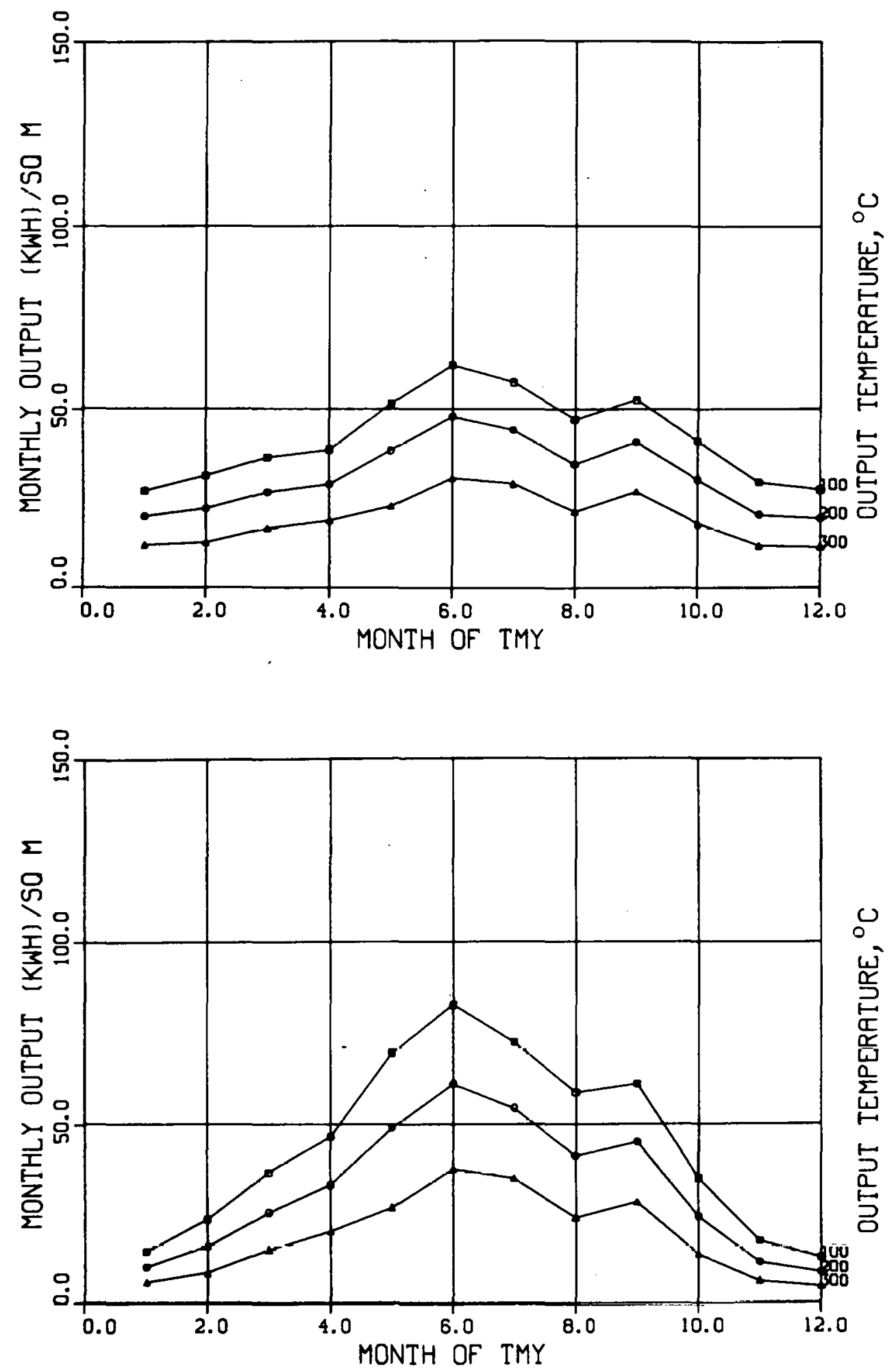

Figure 8. Thermal Output of the Solar Kinetics T-700 Collector with FEK 244 Reflector Surface with E-W and N-S orientation and Boston TMY Solar Data 
Table 1

Predicted Annual Thermal Output $\left(\mathrm{kWh} / \mathrm{m}^{2} \cdot \mathrm{yr}\right)$

Output Temperature

Solar Energy Available

Fresno

Albuquerque

Fort worth

Charleston

Boston
2260

2583

1764

1358

1173

$$
100^{\circ} \mathrm{C} \quad 200^{\circ} \mathrm{C}
$$

Orientation

$\underline{\mathrm{E}-\mathrm{W}} \quad \underline{\mathrm{N}-\mathrm{S}}$

$999 \quad 1195$

1160

133

805

633

894

Orientation

$\underline{E-W} \quad \underline{N-S}$

$844 \quad 977$

$1001 \quad 1121$

662

702

652

485

480

533

378

505

$300^{\circ} \mathrm{C}$

Orientation $\underline{\mathrm{E}-\mathrm{W}} \quad \underline{\mathrm{N}-\mathrm{S}}$

$639 \quad 712$

$792 \quad 857$

$479 \quad 482$
-315

$315 \quad 298$

236228

Reference

1T. D. Harrison, Midtemperature Solar systems Test Facility Program for Predicting Thermal Performance of Line-Focusing, Concentrating Solar Collectors, SAND80-1964 (Albuquerque: Sandia National Laboratories, November 1980). 
DISTRIBUTION :

TID-4500-R66, UC62 (268), 9/80

AAI Corporation

P.O. Box 6787

Baltimore, MD 21204

Acurex Aerotherm

485 Clyde Avenue

Mountain View, CA 94042

Attn: J. Vindum

Alpha Solarco

1014 Vine Street

Suite 2230

Cincinnati, OH 45202

Applied Solar Resources, Inc. 490 East Pima

Phoenix, AZ 85004

Attn: W. H. Coady

Argonne National Laboratory (3)

9700 South Cass Avenue

Argonne, IL 60439

Attn: K. Reed

W. W. Schertz

R. Winston

BDM Corporation

1801 Randolf Street

Albuquerque, NM 87106

Attn: T. Reynolds

Barber Nichols Engineering

6325 W. 55th Avenue

Årvada, 10080022

Attn: R. G. Olander

Battelle Memorial Institute Pacific Northwest Laboratory P.O. Box 999

Richland, WA 99352

Attn: K. Drumheller

Bechtel National, linc.

P.O. Box 3965

50 Beale street

San Francisco, CA 94119

Attn: E. Y. Lam
Boeing Space Center (2)

M/S 86-01

Kent, WA 98131

Attn: S. Duzick

A. Lunde

Budd Company

Fort Washington, PA 19034

Attn: W. W. Dickhart

The Budd Company

Plastic R\&D Center

356 Executive Drive

Troy, MI 48084

Attn: J. N. Epel

Congressional Research Service

Library of Congress

washington, DC 20540

Attn: H. Bullis

Corning Glass Co.

Corning, NY 14830

Attn: A. F. Shoemaker

Corning Glass Works

Electric Products Division

Corning, NY 14830

Attn: C. M. Lemrow

DSET

Black Canyon Stage

P.O. Box 185

Phoenix, AZ 85029

Attn: G. A. Zerlaut

Del Manufacturing Co. 905 Monterey Pass Road

Monterey Park, CA 91754

Attn: M. M. Delgado

Desert Research Institute Energy

Systcmo Laboratory

1500 Buchanan Blvd.

Boulder City, NV 89005

Attn: J. O. Bradley

Donnelly Mirrors, Inc.

49 West Third Street

Holland, MI 49423

Attn: R. E. Cook 
DISTRIBUTION (Continued)

EPRI

3412 Hillview Avenue

Palo Alto, CA 94303

Attn: J.E. Bigger

E-systems, Inc., Energy Tech.

Center

P.O. Box 226118

Dallas, TX 75266

Attn: R. R. Walters

Edison Electric Institute

90 Park $\Lambda$ venue

New York, NY 10016

Attn: L. O. Elsaesser, Director of Research

Energetics

833 E. Arapahoe Street, Suite 202 Richardson, TX 75081

Attn: G. Bond

Energy Institute

1700 Las Lomas

Albuquerque, NM 87131

Exxon Enterpl ises

P.O. Box 592

Florham Park, NJ 07923

Attn: J. Hamilton

Florida Solar Energy Center (2)

300 State Road, Suite 401

Cape Canaveral, FL 32920

Attn: C. Beech

D. Block

Ford Aerospace and Communications 3939 Fabian Way

Palo Alto, CA 94303

Attn: H. J. Sund

Ford Glass Division

300 Renaissance Center

P.O. Box 43343

Detroit, MI 48243

Attn: P. Bender

Ford Motor Company

Room E-3184

Scientific Research Labs

Dearborn, MI 48121

Attn: W. J. Nagle
General Atomic

P.O. Box 81608

San Diego, CA 92138

Attn: A. Schwartz

General Electric Co.

P.O. Box 8661

Philadelphia, PA 19101

Attn: W. Pijawka

General Motors

Harrison Rariator Divigion

l.noknort, NY

Attn: A. Stocker

General Motors Corporation

Technical Center

Warren, MI 48090

Attn: J. F. Britt

Georgia Institute of Technology

Atlanta, GA 30332.

Attn: J. D. Walton

Georgia Power Company

270 Peachtree, P.O. Box 454.5

Atlanta, GA 30302

Attn: J. Roberts

Haveg Industries, Inc.

$1287 \mathrm{E}$. Imperial Highway

Santa Fe Springs, CA 90670

Attn: D. Lombardo

Hexcel

11711 Dublin Blvd.

Dubīin, ¿Ā 94 b66

Attn: G. P. Branch

Highland Plating

1128 N. Highland

Los Angeles, CA 90038

Attn: M. Faeth

Honeywell, Inc.

Energy Resources Center

2600 Ridgeway Parkway

Minneapolis, MN 55413

Attn: J. R. Williams 
Jacobs Engineering Co. 251 South Lake Avenue

Pasadena, CA 91101

Attn: B. Eldridge

Jet Propulsion Laboratory (3)

4800 Oak Grove Drive

Pasadena, CA 91103

Attn: J. Becker

J. Lucas

V. C. Truscello

Lawrence Berkeley Laboratory University of California

Berkeley, CA 94720

Attn: M. Wallig

Lawrence Livermore Laboratory University of California

P.O. Box 808

Livermore, CA 94500

Attn: W. C. Dickinson

Los Alamos Scientific Lab. (3)

Los Alamos, NM 87545

Attn: J. D. Balcomb

C. D. Bankston

D. P. Grimmer

Martin Marietta Aerospace

P.O. Box 179

Denver, CO 80201

Attn: P. Brown

McDonnell Douglas Astronautics Company (3)

5301 Bolsa Avenue

Huntington Beach, CA 92647

Attn: J. B. Blackmon

J. Rogan

D. Steinmeyer

Motorola Inc.

Government Electronics Division

8201 E. McDowell Road

P.O. Box 1417

Scottsdale, AZ 85252

Attn: R. Kendall

NASA-Lewis Research Center

Cleveland, $\mathrm{OH} \quad 44135$

Attn: R. Hyland
New Mexico State University

Solar Energy Department

Las Cruces, NM 88001

Oak Ridge National Laboratory

P.O. BOX Y

Oak Ridge, TN 37830

Attn: S. I. Kaplan

G. Lawson

W. R. Mixon

Office of Technology Assessment U.S. Congress

washington, DC 20510

Attn: R. Rowberg

Omnium G

1815 Orangethorpe Park

Anaheim, CA 92801

Attn: S. P. Lazzara

PPG Industries, Inc.

1 Gateway Center

Pittsburgh, PA 15222

Attn: R. C. Frounfelter

PPG Industries, Inc.

Glass Research Center

Box 11472

Pittsburgh, PA 15238

Attn: D. L. Thomas

PRC Energy Analysis Company

7600 กld Springholuse Road

McLean, VA 22102

Attn: K. T. Cherian

Scientific Atlanta, Inc. 3845 Pleasantdale Road

Atlanta, GA 30340

Attn: A. Ferguson 
DISTRIBUTION (Continued)

Solar Energy Research Institute (110)

1536 Cole Blvd.

Golden, CO 80401

Attn: B. L. Butler

L. G. Dunham (4)

B. P. Gupta

F. Kreith

J. Thornton

K. Touryan

N. Woodley

A. Lewandowski (100)

Solar Energy Technology

Rocketdyne Division

6633 Canoga Avenue

Conoga Park, CA 91304

Attn: J. M. Friefeld

Solar Kinetics Inc. (20)

P.O. Box 47045

Dallas, TX 75247

Attn: G. Hutchinson

Southwest Research Institute

P.O. Box 28510

Sán Anton10, ix 78284

Attn: D. M. Deffenbaugh

Stanford Research Institute Menlo Park, CA 94025

Attn: A. J. Slemmons

Sun Gas Cumpany

Suite 800,2 No. Pk, E

Dallas, TX 75231

Attn: R. S. Slark

Sundstrand Electric Power

4747 Harrison Avenue

Rockford, IL 61101

Attn: A. W. Adam

Sun-Heet, Inc.

2624 S. Zuni

Englewood, co 80110

Suntec Systems Inc. 2101 Wooddale Drive

St. Paul, MN 55110

Attn: L. W. Rees
Swedlow, Inc.

12122 Western Avenue

Garden Grove, CA 92645

Attn: E. Nixon

TRW, Inc.

Energy Systems Group of TRW, Inc.

One Space Park

Bldg. R4, Room 2.074

Redondo Beach, CA 90278

Attn: J. M. Cherne

Texas Tech University

Dept. of Electrical Engineering

P.O. Box 4709

Lubbock, TX 79409

Attn: J. D. Reichert

Toltec Industries, Inc:

40 th and East Main

Clear Lake, IA 50428

Attn: D. Chenault

U.S. Department of Energy (3) Albuquerque Operations Office P.O. Box 5400

Alvuquerque, NM 87185

Attn: G. N. Pappas

C. B. Quimn

J. Weisiger

U.S. Department of Energy Division of Energy Storage

systems

Washington, DC 20545

Attn: J. Gahimer

U.S. Department of Energy

Division of Solar Thermal

Energy Systems

Washington, DC 20545

Attn: W. W. Auer

G. W. Braun

J. E. Greyerbiehl

M. U. Gutstein

L. Melamed

J. E. Rannels

F. Wilkin 
DISTRIBUTION (Continued)

U.S. Department of Energy (2)

San Francisco Operations office

1333 Broadway, Wells Fargo Bldg.

Oakland, CA 94612

Attn: R. W. Hughey

University of New Mexico (2)

Department of Mechanical Eng.

Albuquerque, NM 87113

Attn: W. A. Cross

M. W. Wilden

Veterans Administration

Director, Research Staff

office of Construction

washington, DC 20420

Attn: Bill Schmidt

Westinghouse Electric Corp.

P.O. Box 10864

Pittsburgh, PA 15236

Attn: J. Buggy

1520 T. J. Hoban

1530 W. E. Caldes

1550 F. W. Neilson

2320 K. L. Gillespie

2323 C. M. Gabriel

2324 R. S. Pinkham

2326 G. M. Heck

3161 J. E. Mitchell

3600 R. W. Hunnicutt

Attn: H. H. Pastorius, 3640

3700 J. C. Strassell

4000 A. Narath

4231 J. H. Renken

$4700 \mathrm{~J} . \mathrm{H}$. Scott

4710 G. E. Brandvold

4713 B. W. Marshall

4714 R. P. Stromberg (20)

4715 R. H. Braasch

4718 E. Burgess

4719 D. G. Schueler

4720 V. L. Dugan (100)

4721 Author (20)

4721 J. V. Otts

4722 J. F. Banas

4723 W. P. Schimmel

4725 J. A. Leonard

4730 H. M. Stoller
5510
D. B. Hayes
5520
T. B. Lane
5523
R. C. Reuter
5810
5820
5830
5833
5840
8450
8450
8451
8452
8453
8266
3141
3151
R. G. Kepler
R. E. Whan
M. J. Davis
J. L. Jellison
H. J. Saxton
R. Wayne
T. T. Bramlette
P. Eicker
A. C. Skinrood
W. G. Wilson
E. A. Aas (2)
T. L. Werner (5)
W. L. Garner (3)
For DOE/TIC
(Unlimited Release)
6011 Patents 


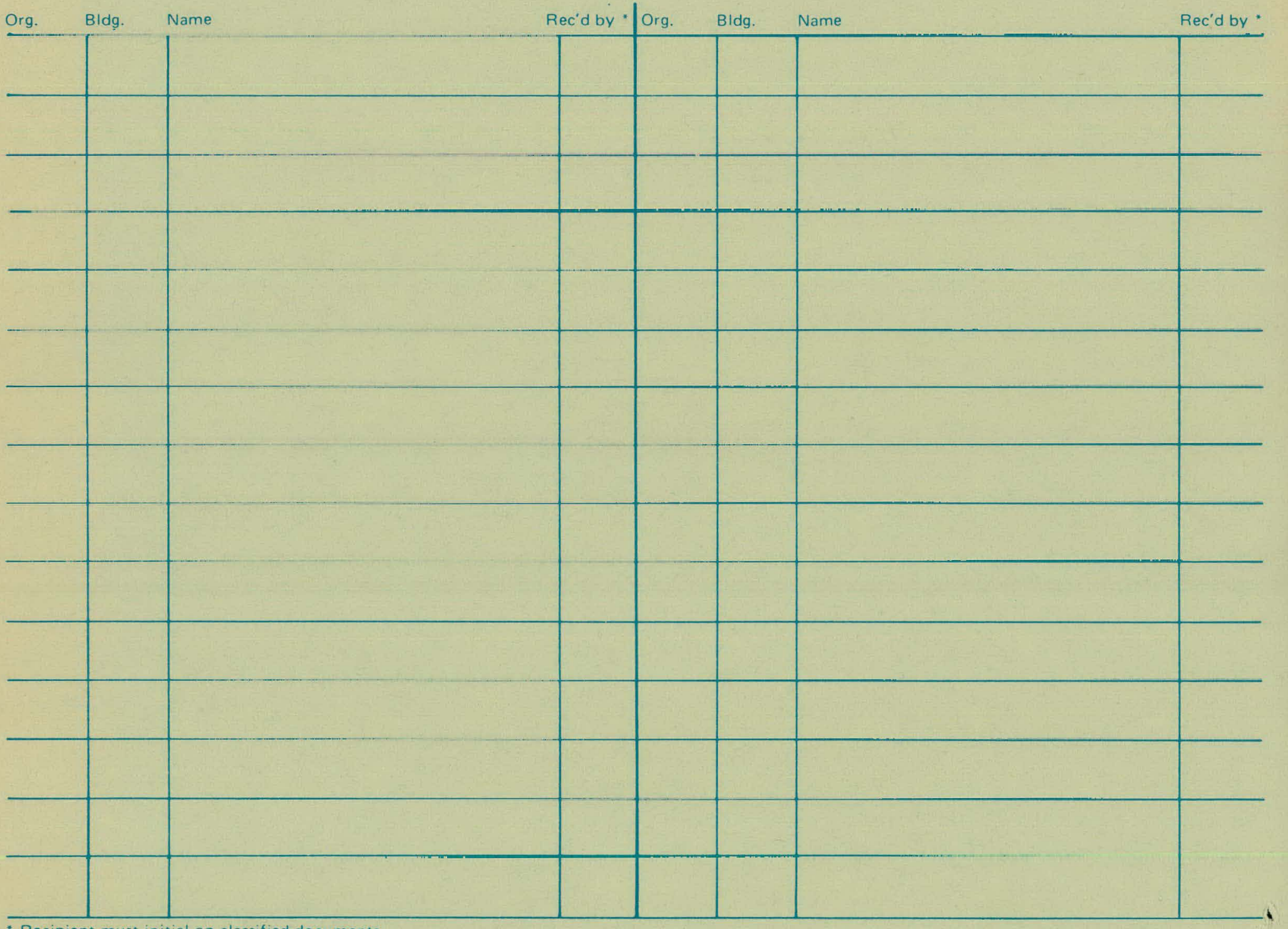

- Recipient must initial on classified documents. 